\title{
Geographical displacement or diffusion of benefit around area-based interventions? Evidence from the New Deal for Communities
}

\author{
Adam Whitworth1* and David McLennan² \\ 1 Dept of Geography, University of Sheffield \\ 2 Social Disadvantage Research Centre, University of Oxford
}

\begin{abstract}
Summary
Area-based interventions (ABIs) have been a popular policy approach since the 1960 s at least in the UK context yet they are bedevilled by concerns that gains in the intervention area may be a result of displacement of problems to neighbouring areas. The arrival of the New Labour government in 1997 saw a surge in 'localism' of a variety of forms, including the innovative and intensive New Deal for Communities ABI. This paper presents findings of a national evaluation of the crime strand of the NDC Programme which focussed on assessing evidence of geographical displacement. There is virtually no evidence of displacement around the NDC Partnerships but there is relatively widespread diffusion of benefit from the Programme to neighbouring areas. Fears of policy-makers and practitioners that ABls will cause geographical displacement of social problems to nearby areas look unfounded and diffusion of benefit seems much more likely.
\end{abstract}

Keywords: New Deal for Communities, geographical displacement, diffusion of benefit, crime evaluation, area-based intervention, weighted displacement quotient.

\section{Introduction}

There is a wealth of research evidence showing that crime tends to concentrate both in time and in space (Weisburd et al., 2008; Anselin et al., 2000; Sherman et al., 1989). In policy terms, crime prevention strategies often target crime 'hot spots' in order both to tackle particularly crime disadvantaged areas and to maximise gains from crime interventions. At the same time, such area-based crime interventions are bedevilled by concerns that crimes prevented may simply be displaced (Cornish and Clarke, 1987; Barr and Pease, 1990; Clarke, 1992; Clarke and Weisburd, 1994). Given the popularity of area-based interventions it is important to assess evidence for displacement and diffusion of benefit around such programmes as any such spill-over effects (whether positive or negative) will affect the net impact of crime interventions as well as altering the distribution of crime in a range of potential ways. 
Six types of displacement are typically identified in the literature (temporal, tactical, situation, type, geographic and perpetrator) and displacement can occur across more than one of these six types at the same time (Repetto, 1974). The focus of this paper is geographical crime displacement in which crimes prevented in an intervention area are pushed into surrounding areas. In contrast to geographical displacement of crime is geographical diffusion of benefit, where in addition to the direct gains in the target area there are additional positive spill-overs in terms of reduced crime levels in neighbouring areas. Routine activities theory is a helpful perspective in asking why geographical displacement/diffusion might occur. The theory argues that crime has the potential to occur when three factors converge in space and time: motivated offenders; suitable targets; and the absence of capable guardians (Cohen and Felson, 1979). If the number of suitable targets is reduced in the intervention area (for example via target hardening schemes) and the number of capable guardians is increased (for example additional police or CCTV) then one might expect a reduction in crime in that area. However, if the intervention is not also focused on reducing the propensity for motivated offenders to commit crimes (for example by tackling the causes of crime such as the lack of employment opportunities or drugs misuse) then potential offenders may recast their target area and commit offences in the surrounding nonintervention neighbourhoods, thus leading to geographical displacement of crime. Alternatively, however, diffusion of benefit to nearby areas may be generated by the intervention if it successfully apprehends prolific offenders or if root causes of crime (e.g. worklessness) are tackled, leading to crime reductions in neighbouring areas as well as in the intervention area itself.

Whilst evaluations of area-based crime interventions have frequently neglected considerations of potential geographic displacement or diffusion there have been various previous evaluations which have incorporated these issues (see for instance Green, 1995; Sherman and Rogan, 1995; Barclay et al., 1996; Braga et al., 1999), including those with a UK focus (Bowers and Johnson, 2003; Bowers et al., 2003a). There have been at least three relatively recent meta-evaluations which summarise findings from a broad range of individual studies across a number of countries (Eck, 1993; Hesseling, 1994; Braga, 2001) which find that although fear of geographical crime displacement permeates much of the policy discourse there is relatively limited evidence that it occurs and at least as much evidence of positive diffusion of benefit to surrounding areas.

\section{Policy context}

A succession of area-based initiatives (ABIs) since the 1960s at least have sought to improve the conditions of the most deprived areas in the UK and to narrow the gaps both in terms of current circumstances and future prospects - between the most and least deprived parts of the country (Smith, 1999). Since the arrival of the New Labour government in England in 1997 the local level has become a central area of policy activity, whether that be in relation to community governance (CLG, 2006), active local citizenship (CLG, 2008) or locally based (and often also locally driven) interventions (Griggs et al., 2008). In terms of community regeneration in particular, New Labour's National Strategy for Neighbourhood Renewal has been the guiding framework for a range of ABls over the last decade including: the Neighbourhood Renewal Fund for the 88 most deprived local authorities; Neighbourhood Wardens; Neighbourhood Management Pathfinders; and the New Deal for Communities (NDCs). The latter, NDCs, represent an innovative, substantial and sustained commitment to the principles of community-based and community-guided ABls (Lawless, 2006) and have been perhaps the clearest articulation of New Labour's philosophy of local devolution in the 
p. 78. Geographical displacement or diffusion of benefit around area-based interventions? Evidence from the New Deal for Communities

remit of regeneration. NDC Partnerships work across five key themes - worklessness, crime, education and skills, health, and housing and the physical environment - and the NDC Programme emphasises a 'bottom up' and 'joined-up' approach to the identification of local needs and the creation of local policy solutions. There are 39 NDC Partnerships across England and these varied in size from between 5,000 and 20,000 residents in 2001 (CRESR, 2005a). Of these 39 NDC Partnerships, 17 Pathfinder Partnerships were announced in 1998 followed by a further 22 Partnerships in 1999. NDCs were rolled out in two phases with funding periods of 2000-2010 and 2001-2011 respectively, with an initial start-up period within these periods preceding policy activity and interventions. Considerable financial resources have been committed to these areas - around $£ 2$ billion over a ten-year period from central government resources (equating to an average of $£ 50$ million per NDC partnership) plus additional funds from a range of other state, private and voluntary organisations at a local level. With these resources NDC Partnerships have initiated a vast array of interventions across the five key operational themes which may impact either directly or indirectly on crime levels.

NDC Partnerships adopted a range of strategies across the crime theme and the differing local contexts and priorities of different NDCs inevitably led to different tailored approaches across the NDC Programme as a whole. Pearson et al (2008) summarise a number of key themes which permeate these approaches: a focus on tackling 'problem' crime types as indicated by police recorded crime statistics; target hardening schemes (e.g. window locks); tackling the fear of crime through an enhanced visible police presence (e.g. CCTV, additional officers and wardens on the streets); preventative and diversionary work with young people; support to victims- and in some cases perpetrators - of crimes; multi-agency working; and working across NDC themes (e.g. indirectly seeking to affect crime through directly targeting problems of worklessness); and a flexible use of resources and strategies to tackle crime 'hotspots'. Whilst flexible and tailored, these common themes are adopted throughout many NDC Partnerships as informed by use of a range of local and national evidence.

The NDC Programme has been extensively evaluated at Programme-wide level by the various members of the National Evaluation Team led by the Centre for Regional Economic and Social Research at Sheffield Hallam University (CRESR, 2005b; CRESR, 2010) as well as by each of the local Partnerships themselves. Working as one research unit within the National Evaluation Team, this paper emerges from a project commissioned by Communities and Local Government (CLG) to investigate the extent to which there is evidence of geographical displacement of crime around the 39 NDC Partnerships. In doing so the analyses build on - amongst others - previous work in the crime strand of the NDC national evaluation on delivering safer neighbourhoods (CRESR, 2008), crime and fear of crime across the NDC areas (Beatty et al., 2005), the measurement of NDC crime outcomes (particularly Bowers et al., 2003b; Hirschfield et al., 2001) as well as geographical displacement and diffusion of benefit specifically around one case study NDC Partnership (Bowers, et al., 2004). This paper presents evidence across the NDC Programme as a whole to contribute to these research findings. Before turning to the main findings the following sections set out the data and methods used.

\section{Data}

The data used in this analysis are individual point-level recorded crime data for all police forces in England containing NDC Partnerships. For the purposes of this evaluation 33 Home Office crime categories are combined into four broad crime types of violence, burglary, theft and criminal damage. Data are held for each year from the 
p. 79. Geographical displacement or diffusion of benefit around area-based interventions? Evidence from the New Deal for Communities

2000/01 period (April to March) to the 2004/05 period. The 2000/01 serves as the starting period for this evaluation and, whilst there is no common starting point for programme activity across the NDC Programme, this broadly maps to the time point at which NDC Partnerships moved from initial organisational activities to beginning to spend resources and roll out interventions.

These recorded crime data are mapped to a number of standard and non-standard geographies required for the evaluation. First, crime counts are mapped from pointlevel to two designer geographies: the 39 NDC Partnerships and to 5 concentric and non-overlapping buffer rings of $200 \mathrm{~m}$ width each around these 39 NDC Partnerships (i.e. the outer edge of the fifth buffer ring is one kilometre from the NDC boundary). Second, crimes are taken to two more standard geographies discussed below: Middle Layer Super Output Areas (MSOAs) and 'wider local areas' (similar to local authorities). To do so crime counts are initially mapped to Output Area (OA) level. OAs are a small area level administrative geography of which there are 165,655 in England with an average of 150 households each. As the location of point-level crime data is not always known or reliable, where mapped points fall within $100 \mathrm{~m}$ of multiple OA boundaries the crime is apportioned equally between such OAs. OA crime counts are then constrained to published Home Office crime counts for Crime and Disorder Reduction Partnerships before being aggregated to MSOAs and 'wider local areas'. There are 6,781 MSOAs in England with an average resident population of 7,300 in 2001. The 'wider local area' represents the NDC Partnership's parent local authority minus any MSOA with greater than 10 per cent of its resident population within an NDC Partnership or buffer area in any year from 2000 to 2004 . These areas are removed in order to remove the potential contamination effects of including areas which can be expected might be affected by the NDC Programme.

At each of these geographical scales, the data are used to create four outcome indicators (violence, burglary, theft, and criminal damage) for each time period (2000/01-2004/05). Each outcome indicator is a rate expressed per 1,000 of the 'at risk' population (total resident and commercial properties for burglary; resident population minus the prison population and plus the 2001 workplace population for violence, theft and criminal damage).

\section{Methodology}

In order to measure geographical displacement/diffusion around each of these NDC Partnerships the evaluation adopted the Weighted Displacement Quotient (WDQ) methodology developed by Bowers et al (Bowers and Johnson, 2003; Bowers et al., 2003a). The WDQ assumes that where crime in the intervention area falls and crime in the buffer area increases that this is suggestive of geographical displacement. Conversely, where crime falls in the intervention area and also falls in the proximate buffer area(s) this is taken to be suggestive of displacement of benefit (the 'halo' or 'free-rider' effect). One advantage of the WDQ is that it makes explicit the fact that displacement/diffusion to proximate areas is only possible where the intervention area experiences a reduction in its level of crime.

The use of the WDQ methodology involves three component steps across which the methodology used is similar: (1) measure change in the intervention areas (given that displacement/diffusion are said to be caused by changes in the intervention area); (2) measure change in the buffer rings; and (3) combine the two to estimate the WDQ. A detailed account of the methodology can be found elsewhere (McLennan and Whitworth, 2008) and is not repeated here. In brief, and relating to Step 1 above (i.e. identifying NDCs suggestive of programmatic crime reductions), the method essentially 
p. 80. Geographical displacement or diffusion of benefit around area-based interventions? Evidence from the New Deal for Communities

calculates the change in crime over time in the NDC area and compares this with the change in the same crime over the same time period seen in a pool of matched control areas. Where this ratio is greater than one this suggests that the change in the NDC area is greater than would be expected based on the changes seen in the control areas. This method is used to firstly identify those NDC intervention areas showing evidence suggestive of NDC-related reductions in crime. It is then repeated with buffer rings rather than NDCs as the focus in order to identify those buffer rings which have seen a greater change in crime than would be expected (based on the changes seen in its matched control areas). Finally, these two sets of information - the changes seen in the intervention area and in its buffer rings - are brought together to calculate a WDQ figure of geographical displacement/diffusion for each relevant buffer ring. This indicates if there is evidence of geographical displacement of diffusion of benefit and the WDQ is also tested for statistical robustness.

More fully, and again in relation to Step 1 above, for each crime type the method calculates the ratio of crime in the target area (e.g. NDC) to crime in the wider local area and then calculates the change in this ratio over each consecutive time period (e.g. 2000/01-2001/02, etc). The assumption is that, other things equal, this ratio will be stable over time. In order to improve the robustness of the methodology, each NDC area is matched to a pool of MSOA control areas with similar characteristics in terms of levels of multiple deprivation and of the crime type in question in 2001. One difficulty is the problem of finding 'sterile' control areas for an evaluation of an intervention such as the NDC given that, by necessity, matched areas will be deprived and may well themselves also be receiving other interventions. This is an issue to which the discussion later returns. Farrington and Welsh (2006; 2002) outline how odds ratios can be used to compare changes in outcomes. Following their approach, comparing the ratios of change seen in the intervention area with the equivalent ratios of change seen in each of its respective matched control areas reveals the extent to which the change in crime in the intervention area differs from the level that would be expected in the absence of the NDC Programme: odds ratios greater than one suggest the change in crime in the intervention area is better than would be expected whilst odds ratios less than one suggest that the change in crime is worse than would be expected. A final element in the methodology uses the work of Johnson et al (2004) on spatial variation to assess the extent to which statistical confidence can be placed in these findings. Using the same steps as outlined above, a background distribution of odds ratios is created which essentially describes the level of change expected and which is used as a benchmark of expected change against which to compare the estimated series of odds ratios.

In this evaluation the $15^{\text {th }}$ and $85^{\text {th }}$ percentiles were considered to be appropriate thresholds at which to evaluate the statistical robustness of findings for two reasons. Firstly, the larger size of NDCs compared to MSOAs means that, other things being equal, there is greater variance in NDC trends than in MSOA trends and this makes it less likely, other things equal, that intervention areas will reach the tails of the distribution (and therefore be identified as having statistically robust change). Secondly, a common difficulty across area-based interventions is that in reality many of the control areas will also have been subject to interventions which can be expected either directly or indirectly - to have affected crime outcomes. Both of these issues would act to understate any potential intervention effects and more relaxed statistical thresholds are therefore adopted in response.

Two limitations of the method in particular are acknowledged. Firstly, whilst suggestive of displacement/diffusion the WDQ is not able to prove a causal relationship between the NDC Programme and crime change in the intervention area, nor between crime change in the intervention area and in the buffer rings. This is a not 
p. 81. Geographical displacement or diffusion of benefit around area-based interventions? Evidence from the New Deal for Communities

uncommon problem in evaluations of any design. Related, the discussion of findings below should be understood as evidence of potential displacement/diffusion based on statistically robust WDQ findings rather than as causal proof of the displacement/diffusion suggested by these findings. For ease of explanation these caveats are acknowledged here and are not repeated throughout the discussion of findings.

\section{Findings}

As outlined above, a necessary first step in the analysis is to identify intervention areas which show robust evidence suggestive of reductions in crime. Pearson (2009) highlights that the levels and experience of crime in NDC areas have improved over the lifetime of the intervention both in terms of resident's perceptions and in terms of the incidence of key crimes. In this evaluation, with the methodology comparing trends in each NDC against trends seen in matched control areas, there is some evidence suggestive of NDC-related reductions in crime over the period analysed, but this is rather limited. Table 1 below outlines the findings for the 36 NDC Partnerships analysed (3 NDC Partnerships could not be evaluated as no suitable control areas could be found). Each of these intervention areas could potentially experience a reduction in crime in any year and on any crime type giving a maximum of 576 instances (i.e. 36 NDCs across 4 crime types and 4 time periods). Over the entire period of analysis there are 77 instances of NDC Partnerships showing statistically robust reductions in crime which equates to 13.4 per cent of the 576 maximum possible number of crime reductions which could have occurred. The results are spread relatively evenly across the four crime types although there were slightly more instances of reductions in burglary, and there were notably fewer NDCs with reductions in crime over the 2001/02-2002/03 time period. This suggests that impacts may grow during the lifetime of the intervention so that one would expect more evidence of programmatic reductions over the second half of the programme's lifetime.

Table 1: Number of NDC Partnerships exhibiting reductions in crime per crime type and per year

\begin{tabular}{|c|c|c|c|c|c|}
\hline & Violence & Burglary & Theft & $\begin{array}{l}\text { Criminal } \\
\text { Damage }\end{array}$ & $\begin{array}{l}\text { All crime } \\
\text { types }\end{array}$ \\
\hline $2000 / 01$ to $2001 / 02$ & 4 & 6 & 5 & 7 & 22 \\
\hline $2001 / 02$ to $2002 / 03$ & 3 & 2 & 4 & 3 & 12 \\
\hline $2002 / 03$ to $2003 / 04$ & 4 & 9 & 5 & 6 & 24 \\
\hline $2003 / 04$ to $2004 / 05$ & 6 & 7 & 2 & 4 & 19 \\
\hline All four time periods & 17 & 24 & 16 & 20 & 77 \\
\hline $\begin{array}{l}\text { Maximum potential } \\
\text { number of reductions }\end{array}$ & 144 & 144 & 144 & 144 & 576 \\
\hline
\end{tabular}

In terms of evidence of geographical displacement or diffusion of benefit around these instances of NDC crime reductions, 77 instances of NDC reductions correspond to 383 potential instances where displacement/diffusion effects within buffer rings might occur (383 rather than 385 potential instances as no suitable matched controls could be found for two buffer rings). Table 2 shows that in around three-quarters of these instances there is no robust evidence either of geographical displacement of crime or of diffusion of benefit. Where there is evidence of change, however, there is much more evidence of positive diffusion of benefit to buffer rings than of crime displacement. Indeed, geographical displacement of crime to these buffer rings appears an extremely rare phenomenon. Across the NDC Programme between 
p. 82. Geographical displacement or diffusion of benefit around area-based interventions? Evidence from the New Deal for Communities

2000/01 to 2004/05, 23 per cent of potential instances of displacement or diffusion suggest diffusion of benefit compared to just 2 per cent which suggest displacement of crime. These findings are consistent across the four time periods and across the four crime types examined.

Table 2: Geographical crime displacement and diffusion of benefit around NDC Partnerships

\begin{tabular}{lccccc}
\hline & $\begin{array}{c}\text { Number of } \\
\text { NDCs with } \\
\text { programme } \\
\text { impact }\end{array}$ & $\begin{array}{c}\text { Number of } \\
\text { concentric } \\
\text { buffers rings } \\
\text { assessed }\end{array}$ & No change & $\begin{array}{c}\text { Buffer rings } \\
\text { with } \\
\text { displacement }\end{array}$ & $\begin{array}{c}\text { Buffer } \\
\text { rings with } \\
\text { diffusion }\end{array}$ \\
\hline Violence & 17 & 85 & $78 \%$ & $1 \%$ & $21 \%$ \\
\hline Burglary & 24 & 120 & $74 \%$ & $1 \%$ & $25 \%$ \\
\hline Theft & 16 & 80 & $70 \%$ & $5 \%$ & $25 \%$ \\
\hline Criminal Damage & 20 & 98 & $79 \%$ & $0 \%$ & $21 \%$ \\
\hline All crime types & 77 & 383 & $75 \%$ & $2 \%$ & $23 \%$ \\
\hline
\end{tabular}

Given that diffusion of benefit accounts for the vast majority of the effects in buffer rings the remainder of the paper focuses exclusively on evidence of geographical diffusion of benefit. Looking at the detailed findings in Table 3, most of the instances of diffusion around an NDC relate to the same crime type and are time-limited in that they occur within the same time period and across multiple buffer rings. However, diffusion of benefit is only rarely seen in the same time point across more than one crime type and never across successive years for the same crime type. For example, there is evidence of diffusion relating to theft in all five buffer rings around Wolverhampton NDC in the 2002/03-2003/04 time comparison period. It is much less common, however, to find consistency of effects in the same buffer ring between crime types. There are some exceptions to this case. Lambeth NDC, for instance, shows diffusion to three buffer rings in the 2002/03-2003/04 period for both burglary and theft. Additionally, there is little consistency in diffusion effects in the same NDC partnership across consecutive years. For example, Tower Hamlets NDC shows diffusion of benefit relating to burglary in all five buffer rings in the 2001/02-2002/03 period but not in the following - or indeed any other - time period. 
p. 83. Geographical displacement or diffusion of benefit around area-based interventions? Evidence from the New Deal for Communities

Table 3: Instances of buffer ring diffusion by crime type, time period and NDC

\begin{tabular}{|c|c|c|c|c|}
\hline & $\begin{array}{l}2000 / 01 \text { to } \\
2001 / 02\end{array}$ & $\begin{array}{l}2001 / 02 \text { to } \\
2002 / 03\end{array}$ & $\begin{array}{c}2002 / 03 \text { to } \\
2003 / 04\end{array}$ & $\begin{array}{c}2003 / 04 \text { to } \\
2004 / 05\end{array}$ \\
\hline \multicolumn{5}{|l|}{ Violence } \\
\hline Buffer 1 & $\begin{array}{c}\text { Sandwell } \\
\text { Sheffield } \\
\text { Salford } \\
\text { Oldham } \\
\text { H'smith \& Fulham }\end{array}$ & & & Tower Hamlets \\
\hline Buffer 2 & Sandwell & & $\begin{array}{c}\text { Bradford } \\
\text { Birmingham } \\
\text { Aston }\end{array}$ & \\
\hline Buffer 3 & Sandwell & Bristol & $\begin{array}{l}\text { Birmingham } \\
\text { Aston }\end{array}$ & \\
\hline Buffer 4 & & Bristol & Bradford & Tower Hamlets \\
\hline Buffer 5 & & $\begin{array}{c}\text { Bristol } \\
\text { Sheffield } \\
\end{array}$ & Bradford & \\
\hline \multicolumn{5}{|l|}{ Burglary } \\
\hline Buffer 1 & $\begin{array}{c}\text { Newham } \\
\text { Salford } \\
\text { H'smith \& Fulham }\end{array}$ & Tower Hamlets & $\begin{array}{l}\text { Lewisham } \\
\text { Lambeth }\end{array}$ & $\begin{array}{l}\text { Walsall } \\
\text { Coventry }\end{array}$ \\
\hline Buffer 2 & $\begin{array}{c}\text { Salford } \\
\text { H'smith \& Fulham }\end{array}$ & Tower Hamlets & $\begin{array}{l}\text { Liverpool } \\
\text { Lewisham } \\
\text { Lambeth } \\
\text { Birmingham } \\
\text { Aston }\end{array}$ & $\begin{array}{l}\text { Walsall } \\
\text { Haringey } \\
\text { Coventry }\end{array}$ \\
\hline Buffer 3 & $\begin{array}{c}\text { Salford } \\
\text { H'smith \& Fulham }\end{array}$ & Tower Hamlets & $\begin{array}{l}\text { Liverpool } \\
\text { Lewisham } \\
\text { Lambeth }\end{array}$ & \\
\hline Buffer 4 & Salford & Tower Hamlets & & Walsall \\
\hline Buffer 5 & & $\begin{array}{c}\text { Tower Hamlets } \\
\text { Coventry }\end{array}$ & & Walsall \\
\hline \multicolumn{5}{|l|}{ Theft } \\
\hline Buffer 1 & Coventry & $\begin{array}{l}\text { Sandwell } \\
\text { Hartlepool }\end{array}$ & $\begin{array}{c}\text { Wolverhampton } \\
\text { Lambeth }\end{array}$ & \\
\hline Buffer 2 & Coventry & $\begin{array}{l}\text { Brighton } \\
\text { Sandwell }\end{array}$ & $\begin{array}{c}\text { Wolverhampton } \\
\text { Lambeth }\end{array}$ & \\
\hline Buffer 3 & & $\begin{array}{l}\text { Sandwell } \\
\text { Hartlepool }\end{array}$ & $\begin{array}{l}\text { Wolverhampton } \\
\text { Lambeth }\end{array}$ & \\
\hline Buffer 4 & & $\begin{array}{l}\text { Sandwell } \\
\text { Hartlepool }\end{array}$ & Wolverhampton & \\
\hline Buffer 5 & & Sandwell & Wolverhampton & \\
\hline \multicolumn{5}{|c|}{ Criminal Damage } \\
\hline Buffer 1 & $\begin{array}{l}\text { Newcastle } \\
\text { Knowsley } \\
\text { Doncaster }\end{array}$ & $\begin{array}{l}\text { Liverpool } \\
\text { Bradford }\end{array}$ & Tower Hamlets & $\begin{array}{l}\text { Liverpool } \\
\text { Brent }\end{array}$ \\
\hline Buffer 2 & Doncaster & Bradford & $\begin{array}{l}\text { Tower Hamlets } \\
\text { Sheffield }\end{array}$ & $\begin{array}{l}\text { Liverpool } \\
\text { Sandwell } \\
\text { Bristol }\end{array}$ \\
\hline Buffer 3 & & Bradford & Sheffield & \\
\hline Buffer 4 & Rochdale & & Sheffield & \\
\hline Buffer 5 & Rochdale & & Sheffield & \\
\hline
\end{tabular}


p. 84. Geographical displacement or diffusion of benefit around area-based interventions? Evidence from the New Deal for Communities

One common aspect of analyses of geographical crime displacement/diffusion is to look at 'distance decay' which refers to the notion that effects weaken as distance from the intervention area increases. Within the existing evidence base there is support for the view that distance decay does exist in practice (Phillips, 1980; Rengert and Wasilchick, 1985; van Koppen and de Keijser, 1997), though mediated by factors such as knowledge of proximate areas and travel-to-crime patterns in addition to distance (Rengert et al., 1999; Wiles and Costello, 2000).

The final column in Table 4 suggests that there is support for the existence of distance decay effects across the diffusion findings: buffer ring one exhibits almost three times the number of instances of diffusion of benefit compared to buffer ring five. There is a consistent pattern of decreasing instances of diffusion of benefit when moving to more distant buffer rings and this pattern is consistent across the four individual crime types.

Table 4: Spatial distribution of diffusion across buffer rings

\begin{tabular}{lccccc}
\hline & Violence & Burglary & Theft & $\begin{array}{c}\text { Criminal } \\
\text { Damage }\end{array}$ & $\begin{array}{c}\text { Sum of four } \\
\text { crime types }\end{array}$ \\
\hline Buffer 1 & 6 & 8 & 7 & 8 & 29 \\
Buffer 2 & 3 & 10 & 4 & 7 & 24 \\
Buffer 3 & 3 & 6 & 4 & 2 & 15 \\
Buffer 4 & 3 & 3 & 3 & 2 & 11 \\
Buffer 5 & 3 & 3 & 2 & 2 & 10 \\
\hline
\end{tabular}

However, one methodological factor which may be linked to these findings is the fact that a standardised statistical test was applied to each of the five buffer rings. Given the same statistical threshold across the five buffer rings, it will tend to be relatively easier for smaller inner buffer rings compared with larger outer buffer rings to reach the tails of the background distribution and, as such, to record evidence of diffusion. Table 5 examines whether there is evidence that this methodological issue drives the distance decay findings outlined above. For each of the five buffer rings across all 36 NDC Partnerships as a whole, column two shows the mean ratio of the buffer ring's 2001 resident population compared with the 2001 resident population of MSOAs in the same PFA where a ratio of one implies that the two areas are of equivalent population size. One simple way to explore whether the use of standardised statistical thresholds may be driving apparent distance decay effects is to vary the statistical thresholds applied across the five buffer rings according to their respective population ratios and to assess the impact on the findings.

Three sets of alternative statistical thresholds are tested. The first set of statistical thresholds corresponds to those used in the project and on which the results presented above are based. Here each buffer ring's mean WDQ odds ratio must be beyond the $85^{\text {th }}$ percentile of the background distribution of odds ratios in order to be considered robust evidence of geographical diffusion.

The second set of statistical thresholds vary the points beyond which each buffer ring's mean WDQ odds ratio must fall within the background distribution in order to be considered statistically robust. There is no obvious level at which to set these varying statistical thresholds but those set out in Table 5 are considered reasonable indicators. On average the third buffer rings exhibit a buffer ring to MSOA mean population ratio of 1.29. The statistical threshold applied to this buffer ring is that of the $85^{\text {th }}$ percentile within the background distribution. For the larger outer buffer rings - where the buffer ratio is higher and where it is, other things equal, therefore relatively more difficult for the buffer ring to reach the tails of the background distribution - the statistical 
p. 85. Geographical displacement or diffusion of benefit around area-based interventions? Evidence from the New Deal for Communities

threshold applied is more relaxed. For the smaller inner buffer rings the opposite is true and more stringent thresholds are applied. Whilst the findings are not entirely consistent across the five buffer rings (buffer ring 5 shows more evidence of diffusion of benefit than buffer ring four for example), in general these results do not suggest that the distance decay effects presented in Table 4 are driven by the standardised statistical thresholds used in the methodology.

The third set of statistical thresholds applies an even greater difference between the tests applied to the inner and outer buffer rings. Even here there is some evidence for distance decay effects, with the inner two buffer rings showing greater evidence of diffusion effects compared with the outer three buffer rings but otherwise with no consistent or gradual change in the number of instances of diffusion across the five buffer rings. Hence, evidence of apparent distance decay effects continue to be apparent - although to a less dramatic and less consistent degree - when statistical thresholds are adjusted to take account of differing population sizes across the buffer rings.

Table 5: Sensitivity of geographical diffusion distance decay findings to alternative statistical thresholds

\begin{tabular}{cccccccc}
\hline $\begin{array}{c}\text { Buffer } \\
\text { ring }\end{array}$ & $\begin{array}{c}\text { Buffer ring: } \\
\text { Mean MSOA } \\
\text { population } \\
\text { ratio }\end{array}$ & $\begin{array}{c}\text { Sut } \\
\text { (as in Table 3) }\end{array}$ & $\begin{array}{c}\text { Instances } \\
\text { of } \\
\text { points }\end{array}$ & $\begin{array}{c}\text { Cut } \\
\text { points } \\
\text { apparent } \\
\text { diffusion }\end{array}$ & $\begin{array}{c}\text { Instances } \\
\text { of } \\
\text { apparent } \\
\text { diffusion }\end{array}$ & $\begin{array}{c}\text { Cut } \\
\text { points }\end{array}$ & $\begin{array}{c}\text { Instances } \\
\text { of } \\
\text { apparent } \\
\text { diffusion }\end{array}$ \\
\hline 1 & 0.95 & 0.85 & 29 & 0.89 & 22 & 0.91 & 17 \\
\hline 2 & 1.06 & 0.85 & 24 & 0.87 & 21 & 0.88 & 18 \\
\hline 3 & 1.29 & 0.85 & 15 & 0.85 & 15 & 0.85 & 15 \\
\hline 4 & 1.45 & 0.85 & 11 & 0.83 & 12 & 0.82 & 15 \\
\hline 5 & 1.55 & 0.85 & 10 & 0.81 & 15 & 0.79 & 15 \\
\hline
\end{tabular}

\section{Discussion}

The paper has described the findings of a robust national evaluation of one of the UK's most significant recent ABIs - the NDC Programme - which aims, amongst other objectives, to reduce levels of crime across the 39 NDC Partnerships. The findings therefore represent an important contribution to the UK - and international - evidence base into geographic displacement and diffusion of benefit around area-based crime interventions. Overall there is relatively limited evidence of the NDC Programme reducing crime levels in the intervention areas, with reductions in crime in NDC Partnerships occurring in around 13 per cent of all possible instances. Where there is evidence of programmatic impact, there is no evidence either of geographical displacement or diffusion of benefit in around three-quarters of the relevant buffer rings.

Importantly, evidence suggesting geographical displacement of crime to surrounding buffer rings is extremely rare and these results confirm the findings of previous meta-evaluations that the fear of displacement around area-based interventions exceeds its reality (Felson and Clarke, 1998: 26). In contrast, a key finding is the evidence to suggest that there had been diffusion of benefit to surrounding areas in around 23 per cent of cases where the potential for 
p. 86. Geographical displacement or diffusion of benefit around area-based interventions? Evidence from the New Deal for Communities

displacement/diffusion existed. Evidence of diffusion of benefits is consistent across the four crime types of violence, theft, burglary and criminal damage as well as across the four time periods analysed. These are important findings for policy-makers and practitioners involved in ABIs who may have concerns about their impacts on nearby areas.

Diffusion of benefit also seems to be widely distributed across the NDC Partnerships, with 24 of the 36 NDC Partnerships analysed showing at least one instance of diffusion. Evidence of diffusion of benefit is often consistent across multiple buffer rings around NDC Partnerships. However, results seemed time-limited and are rarely replicated across consecutive time points or across multiple crime types within the same time period. This may be suggestive of the difficulty in achieving continuous improvements over consecutive years and in achieving successes on different crime fronts. Additionally, there is evidence of distance decay effects in which areas immediately proximate to the intervention areas are affected to a greater degree than more distant areas. These distance decay effects are robust to sensitivity tests and add weight to the evidence for distance decay effects around ABIs. They also make sense in terms of how one might expect an $A B I$ to affect nearby areas and can help policy-makers and practitioners consider which neighbouring geographies might also be affected (almost certainly positively these findings would suggest) by ay ABI.

There is much ground that the discussion has not sought to cover and that the quantitative findings around outcomes and impacts presented above constitute only one part of the overall evidence base required to evaluate and to understand processes within the NDC Programme. Many other forms of evidence are required in order to complement, to triangulate and, crucially, to seek to explain these findings, including mapping these findings onto detailed case study work by National Evaluation Team partners into the specific nature, intensity and timing of interventions across NDC Partnerships (CRESR, 2008). As we move into a post-NDC era within which budgets for ABIs look certain to be cut dramatically, these are central issues in seeking to learn lessons from the NDC experience in order to design more effective (and more cost-effective) area-based crime reduction interventions in the future, with more positive outcomes both for intervention areas themselves as well as for neighbouring geographies. However, to do so a set of robust evidence as to the actual experience of displacement and diffusion around such areas is required in the first instance, and it is to this preliminary end that this paper is intended.

\section{Acknowledgements}

The authors are grateful to Penny Withers and colleagues at CLG for support and helpful comments. The national evaluation of the NDC Programme is led by the Centre for Regional and Social Research (CRESR) at Sheffield Hallam University and the authors would like to thank colleagues at CRESR for their support and comments. The authors are grateful to $\mathrm{Dr}$ Shane Johnson of the Jill Dando Institute, University College London, for his support in developing the methodology.

* Correspondence Address: Dr Adam Whitworth, Dept of Geography, Sheffield University, Winter Street, Sheffield, S10 2TN. Email: adam.whitworth@sheffield.ac.uk. 
p. 87. Geographical displacement or diffusion of benefit around area-based interventions? Evidence from the New Deal for Communities

\section{References}

Anselin, L., Cohen, J., Cook, D., Gorr, W., and Tita, G. (2000) Spatial analyses of crime. Criminal Justice 2000, 4.

Barclay, P., Buckley, J., Brantingham, P., Brantingham, P. and Whinn-Yates, T. (1996) Preventing auto theft in suburban Vancouver commuter lots: effects of a bike patrol, in: Clarke, R. (ed) Preventing Mass Transit Crime. Crime Prevention Studies, Vol. 6. New York: Criminal Justice Press.

Barr, R. and Pease, K. (1990) Crime placement, displacement, and deflection. Crime and Justice, 12, 277-318.

Beatty, C., Grimsley, M., Lawless, P., Manning, J. and Wilson, I. (2005) Fear of Crime in NDC areas: How do Perceptions Relate to Reality? Sheffield: CRESR, Sheffield Hallam University.

Bowers, K. and Johnson, S. (2003) Measuring the geographical displacement and diffusion of benefit effects of crime prevention activity. Criminology, 19, 3, 275301.

Bowers, K., Johnson, S. and Hirschfield, A. (2003a) Pushing back the boundaries: new techniques for assessing the impact of burglary schemes. Home Office Online Report 24/03.

Bowers, K., Johnson, S., Hirschfield, A. and Young, C. (2003b) Investigating the crime reduction claims of NDC partnerships. Research Report 3 - New Deal for Communities - The National Evaluation. Sheffield: CRESR, Sheffield Hallam University.

Bowers, K., Hirschfield, A. and Johnson, S. (2004) Taking an analytical approach to crime prevention in NDC areas. Research Report 44 - New Deal for Communities The National Evaluation. Sheffield: CRESR, Sheffield Hallam University.

Braga, A. (2001) The effects of 'hot spots' policing on crime. Annals of the American Academy of Political and Social Science, 578, 1, 104-125.

Braga, A., Weisburd, D., Waring, E., Mazerolle, L., Spelman, W. and Gajewski, F. (1999) Problem-oriented policing in violent crime places: A randomized controlled experiment. Criminology, 37, 3, 541-80.

Centre for Regional Economic and Social Research (CRESR) (2005a) The 39 NDC areas: Brief pen portraits. Sheffield: CRESR, Sheffield Hallam University.

Centre for Regional Economic and Social Research (CRESR) (2005b) New Deal for Communities 2001-2005: Interim Evaluation. London: ODPM.

Centre for Regional Economic and Social Research (CRESR) (2008) Delivering safer neighbourhoods: Experiences from the New Deal for Communities Programme. London: CLG.

Centre for Regional Economic and Social Research (CRESR) (2010) The New Deal for Communities Experience: A final Assessment. London: CLG.

Clarke, R. (1992), Situational crime prevention: successful case studies. New York: Harrow and Heston.

Clarke, R. and Weisburd, D. (1994) Diffusion of crime control benefits: observations on the reverse of displacement, in: Clarke, R. (ed.) Crime Prevention Studies, 2, 165184.

Cohen, E. and Felson, M. (1979) Social change and crime rate trends: A routine activity approach. American Sociological Review, 44, 588-608.

Communities and Local Government (CLG) (2006) Strong and Prosperous Communities. The Local Government White Paper. London: CLG.

Communities and Local Government (CLG) (2008) Communities in Control: real people, real power. London: The Stationery Office.

Cornish, D. and Clarke, R. (1987) Understanding crime displacement: an application of rational choice theory. Criminology, 25, 4, 933-948. 
p. 88. Geographical displacement or diffusion of benefit around area-based interventions? Evidence from the New Deal for Communities

Eck, J. (1993) The threat of crime displacement. Problem Solving Quarterly, A Police Executive research forum publication, 6, 3, 1-7.

Farrington, D. and Welsh, B. (2002) Effects of improved street lighting on crime: A systematic review. London: Home Office (Research Study No 251).

Farrington, D. and Welsh, B. (2006) How important is 'regression to the mean, in: areabased crime prevention research? Crime Prevention and Community Safety, 8, 50-60.

Felson, M. and Clarke, R. (1998) Opportunity makes the thief: Practical theory for crime prevention. Police Research Series Paper 98. London: Home Office.

Green, L. (1995) Cleaning up drug hotspots in Oakland, California: The displacement and diffusion effects. Justice Quarterly, 12, 4, 737-754.

Griggs, J., Whitworth, A., Walker, R., McLennan, D. and Noble, M. (2008) Person or place-based policies to tackle disadvantage? Not knowing what works. York: Joseph Rowntree Foundation.

Hesseling, R. (1994) Displacement: a review of the empirical literature, in: Clarke, R. (ed.) Crime Prevention Studies, Vol. 3. New York: Criminal Justice Press.

Hirschfield, A., Johnson, S. and Bowers, K. (2001) Review of major policy debates and evidence base: Crime domain - Scoping report. New Deal for Communities - The National Evaluation. Sheffield: Sheffield Hallam University.

Johnson, S., Bowers, K., Jordan, P., Mallender, J., Davidson, N. and Hirschfield, A. (2004) Evaluating crime prevention scheme success: Estimating 'outcomes' or how many crimes were prevented. Evaluation, 10, 3, 327-348.

Lawless, P. (2006) Area-based urban interventions: Rationale and Outcomes: The New Deal for Communities. Urban Studies, 43, 11, 1991-2011.

McLennan, D. and Whitworth, A. (2008) Displacement of Crime or Diffusion of Benefit: Evidence from the New Deal for Communities Programme. London: CLG.

Pearson, S. (2009) How low should you go? Neighbourhood level interventions in the crime and community safety theme of New Deal for Communities. People, Place and Policy Online, 3, 1, 48-57.

Pearson, S., Ardon, R., Lawless, P., Wells, P., Dickinson, S., Fordham, G., Fuller, C., McLennan, D., Whitworth, A. and Meegan, R. (2008) Delivering safer neighbourhoods: Experiences from the New Deal for Communities Programme. London: CLG.

Phillips, P. (1980) Characteristics and typology of the journey to crime, in: GeorgesAbeyie, D. and Harries, K. (eds) Crime: A spatial perspective. New York: Columbia University Press.

Rengert, G. and Wasilchick, J. (1985) Suburban burglary: A time and a place for everything. Springfield, Illinois: Charles Thomas.

Rengert, G., Piquero, A. and Jones, P. (1999) Distance decay re-examined. Criminology, 37, 2, 427-446.

Repetto, T. (1974) Residential Crime. Cambridge, MA: Ballinger.

Sherman, L. and Rogan, D. (1995) Effects of gun seizures on gun violence: 'Hot spots' patrol in North Kansas. Justice Quarterly, 12, 4, 673-694.

Sherman, L., Gartin, P. and Buerger, M. (1989) Hot spots of predatory crime: Routine activities and the criminology of place. Criminology, 27, 1, 27-55.

Smith, G. (1999) Area-based initiatives: the rationale and options for area targeting. London School of Economics: CASE Paper 25.

Van Koppen, P. and de Keijser, J. (1997) Desisting distance decay: on the aggregation of individual crime traps. Criminology, 35, 3, 505-515.

Weisburd, D., Bernasco, W. and Bruinsma, G. (2008), (eds) Putting crime in its place: units of analysis in geographic criminology. New York: Springer.

Wiles, P. and Costello, A. (2000) The 'road to nowhere': the evidence for travelling criminals. Home Office Research Study 207. London: Home Office. 